\title{
Social Currency and Technology An Analysis of Brazilian Social Currencies and the Palmas Case
}

\author{
http://dx.doi.org/10.21527/2237-6453.2019.47.136-155
}

Recebido em: 6/4/2017

Aceito em: 26/12/2018

\section{Ariadne Scalfoni Rigo ${ }^{1}$, Andréa Cardoso Ventura²}

\begin{abstract}
There are plenty of organizations from private, public and nonprofit areas dealing with the current world development crisis. Some studies have shown alternative systems of use of social and complementary currencies. This paper aims to analyze the social currency used by one development bank to improve local economy in a poor community in Brazil, using a specific social technology (ST). We applied an ethnographic approach to the oldest and biggest Brazilian Community Bank (Banco Palmas) and highlight the Palmas social currency creation process and use. This research has allowed the identification of patterns that make possible the ST dissemination to other nonprofit organizations. The results have demonstrated that community banks and their social currencies can play a pervasive role regarding local development, as an effective economic solution technology to reach other disfavored groups. We argue that the reapplication process close social currency use to ST concept.
\end{abstract}

Keywords: Social currency. Social tecnology. Palmas. Brazilian community bank.

\section{MOEDA SOCIAL E TECNOLOGIA: \\ UMA ANÁLISE DAS MOEDAS SOCIAIS BRASILEIRAS E O CASO DAS PALMAS}

\section{RESUMO}

Há muitas organizações privadas, públicas e sem fins lucrativos que lidam com a atual crise mundial de desenvolvimento. Alguns estudos têm mostrado sistemas alternativos de uso de moedas sociais e complementares. Este trabalho tem como objetivo analisar a moeda social usada por um banco de desenvolvimento no intuito de melhorar a economia local em uma comunidade pobre no Brasil, usando uma tecnologia social (TS) específica. Aplicou-se uma abordagem etnográfica ao maior e mais antigo Banco Comunitário do país (Banco Palmas) e destacou-se o processo de criação e uso da moeda social denominada Palmas. Esta pesquisa permitiu a identificação de padrões que possibilitam a disseminação de TS para outras organizações comunitárias e sem fins lucrativos. Os resultados demonstraram que os bancos comunitários e suas moedas sociais podem desempenhar um papel importante no processo de desenvolvimento local, como uma tecnologia que ajuda na solução de problemas econômicos eficaz para alcançar grupos desfavorecidos. Ao final, argumenta-se que o processo de reaplicação do uso da moeda social é coerente com o conceito de TS.

Palavras-chave: Moeda social. Tecnologia social. Palmas. Bancos comunitários brasileiros.

\footnotetext{
${ }^{1}$ Doutora em Administração pela Universidade Federal da Bahia (Ufba). Professora da Universidade Federal da Bahia (Ufba). ariadnescalfoni@gmail.com

${ }^{2}$ Doutora em Administração pela Universidade Federal da Bahia (Ufba). Professora da Universidade Federal da Bahia (Ufba). andreaventurassa@gmail.com
} 
Since the first experiments on the use of complementary currencies in the past 30 years, a variety of scholars have shown interest in the pursuit of understanding the specificities of each experience. They ponder that, especially in Brazil, this move in order to identify similarities and differences in terms of objectives, actors involved, schemes (circuit design) and management methods of these alternative monetary circuits (MENEZES, 2007; MARTIGNONI, 2012). However, Martignoni (2012) warns that, so far, there are few studies that departed differently from the traditional criteria of the economy. These studies can be identified in Blanc (1998, 2011, 2013), Martignoni (2012) and Lemos, Falcoski and Castri (2012). This fact leads us to seek alternative theoretical and interdisciplinary frameworks to understand all experiences and specificities of the social currencies created and used in Brazil.

In general, the aim is to understand the diversity of projects and experiences of complementary currencies and social uses worldwide. However, there is a lack of studies that go beyond the simple differentiation and characterization of experiences. It is necessary to have studies that allow a deep understanding of it, thus enabling a more effective utilization of these development tools in other communities and similar regions.

The more general the denomination "complementary currency" (or parallel currency) is adopted in many countries worldwide. However, this designation typically refers to a diverse group that includes foreign currencies for lucrative commercial purposes, such as company bonuses for customer loyalty (BLANC, 1998). In Europe, the term "social" (social currency) has been recently added, as well as "community" (community currency or local currency, sometimes).

In Brazil, social currencies from exchange clubs as well as those from Community Development Banks (BCDs) have strong focus on social transformation. Thus, the term "social currency" in Brazil is related to the social purpose of its use (mainly by economic improvement) in impoverished territories or groups, seeking alternatives to trade, produce or consume. It is precisely such aim on transformation that brings social currency closer to another concept, also related to the search for improved quality of life and effective social change: Social Technologies (ST). Although it is still considered, by many, a concept under construction, the ST has been widely used in Brazil, being understood, generally speaking, as products, techniques or methods that can be reapplied, developed and/or applied in interaction with the community, representing social transformation solutions through the sustainable use of local resources (RTS, 2011).

This paper presents the beginning of a new line of research, establishing a dialog between two doctoral theses developed in Federal University of Bahia located in northeastern Brazil, in order to understand new technologies created based on accumulated knowledge and action by non-profit organizations, to pursue social transformation. Since the Brazilian Northeast Region displays great social vulnerabilities, there are a variety of experiences being developed to alleviate these problems. In this paper, we focus on analyzing, through diverse methodological procedures (ethnography, interviews and network analysis), social currencies as a significant improvement of alternative technological proposal of exchange of power, held in certain communities. The choice was made because the social currency has been recognized as social technologies, that is, as techniques, methods or procedures developed in interaction with the beneficiaries of 
the technology, subject to reinvestment, and capable of generating social change, as it will be explained in the course of this study. However, for such instrument to be actually considered as a technology capable of bringing social transformation, we need both the analytical depth on the effectiveness of this instrument as well as understanding its embodiment, so it can be used in other communities.

Despite the expressive number of social currencies recognized as ST since 2007, and the existence of a large number of scientific studies that mention this relation (for example: FRANÇA FILHO; SILVA JÚNIOR; RIGO, 2012; MELO NETO SEGUNDO, 2009), they don't present a characterization of why it is really a ST or not. So, there is still a gap in the literature that really analysis a social currency as ST. In addition, there is a lack of studies that try to systematize ST creation, use and reapplication (BAVA, 2004; MIRANDA; LOPEZ; SOARES, 2011), seeking its dissemination as a development tool.

Such attempt can be seen in Lemos, Falcoski and Castri (2012). The authors analyse the community bank implementation, affirming they represent ST. They also emphasize the importance of these banks in the sense that, as ST, they can promote local development, community empowerment and civil organization, since they articulate, concomitantly, production, commercialization, financing and training of the communities in the territory. In the present study, we seek to carry out a deep analysis of one of the most famous social currencies in the world: the Palmas, created by a Community Development Bank called Banco Palmas.

Introducing this paper, we present the notion of complementary and social currency pointing out the main examples around the world. After that, we present the main types of social currencies in Brazil, focusing on the methodology of functioning of community banks and the use of social currencies in the territories where they are located and its relation with the ST concept. We then deepen the notion of ST emphasizing the importance of participation and knowledge of community members in their creation and use. In the method session, we present and justify our methodological choices during the research process. In the discussion session, we first present the process of creating the Banco Palmas and its social currency, and then we discuss the development bank and the its currency as social technologies that can be reapplied and to contribute to local development processes. Finally, we present the main findings and discussions.

\section{PRESENTING EXPERIENCES OF SOCIAL CURRIENCIES USE AROUND THE WORLD}

For a better understanding of the contribution of social currencies as a ST to solve exchanges, and financial and community development problems, it is necessary to know a little about the history of social currencies creation and its main examples.

The Local Exchange Trading Systems (LETS) are, perhaps, the best-known experiences of local currencies. The first LETS was created in 1983 in a village in Canada, because of an economic crisis generated by the transfer of a company to another region (MENEZES, 2007). In this system, people of a community, neighborhood or even a region create a network of service and product exchange, using their own currency. According to Lietaer (2001 apud MENEZES, 2007), there have been more than 2,500 LETSs around the world. 
Similar experiences to Canadian LETS are called SELs (Systèmes d'Échange Local) in France. The main difference between the LETSs and SELs is that the latter use, mostly, virtual currencies (BLANC, 1998; MENEZES, 2007). Each SEL creates its own currency and its own exchange system. The purpose of these systems is to stimulate the exchange of goods and services among people.

It is noticed that the SEL, cited above, resembles the Brazilian and Argentinian exchange clubs. These clubs are groups of a given community, coming together to promote exchange of products, services and knowledge among its members. Each club is organized and it builds an appropriate methodology to its reality, defining, for example, meetings schedule, forms and instruments to mediate exchanges. Emerged in Argentina in 1995, the idea of clubs spreaded rapidly, increasing the number of members and the number of barter clubs throughout the country. During the economic crisis of the begging of the 2000-decade, it became a financial alternative, and it gave rise to a parallel economy. At the height of the financial crisis in that country, in 2002, the number of clubs reached 5,000 , with 2 million members. However, various frauds, related to accounting problems and currency counterfeiting, ended up causing their lack of credibility, moving them away from the solidarity ideology that originated them. Currently, there are about 20 clubs with 4,000 members, which have a local characteristic and seek network integration (FAIRE MOUVEMENT, 2011).

One of the important aspects of the research on social and complementary currencies is that they allow us to reflect upon a presumed "national currency exclusivity" of contemporary economies. According to Blanc (1998, p. 87), "within the framework of contemporary monetary systems, parallel currencies are likely to be everywhere and be used by al". They then invite to (re)think the traditional concept of currency. Also, often, complementary and social currencies are endorsed by governments (BLANC, 1998).

\section{The Specificity of the Social Currency Methodology of Community Banks in Brazil}

In Brazil, there are two main types of social currencies. Social currencies of exchange clubs and social currencies of Community Development Banks (BCDs). The first ones, created in 1998, are directly inspired by the Argentinian and Canadian exchange clubs. They are also seen as alternatives, found by groups and networks to obtain goods and services in difficult economic contexts. Whereas, the second ones are those created specifically by a community bank, that is, institutions that work with microfinance to promote income-generating opportunities within their communities. In fact, the role of community banks involves not only the provision of banking and financial services (including access to credit), but also a number of actions within the community, linked to a larger goal of territorial development (local development).

The BCDs have stood out due to their organizational characteristics and management. They have associative and community nature, and they aim at generating jobs and income in impoverished areas (SILVA JUNIOR, 2004; RIGO, 2014). They greatly differ from conventional microfinance practices as they are created by community members which adopt participatory structures. They are seen as a more effective mechanism of 
financial inclusion for the poorest people, because they are supported by the social relations of the territory and they are based on values such as solidarity and trust. These values allow communal regulation of financial operations.

In summary, the BCDs are characterized by some basic aspects, namely: a) the management structure - the coordination of activities and resources is collective; $b$ ) micro-credit lines for production and local consumption with low interest rates to allow income generation and employment opportunities within the community; c) the loan and collection processes are based on neighborhood relationships and solidarity (the control is more social than economic one); d) the creation of alternative instruments to encourage local consumption - mainly a local social currency - which are recognized and accepted by producers, traders and consumers, in order to stimulate the local economy (FRANÇA FILHO; SILVA JUNIOR, 2009).

Characterized as "practice", the main purpose of BCDs is to promote territorial coordination by local actors - producers, consumers and service providers - through appropriate lending lines that meet the demands of the territory and the creation of its own currency. This currency (social currency) is voluntarily used among residents, traders and local entrepreneurs.

The BCD is characterized by community ownership. This feature is important in two main stages: implementation and development. During implementation, the existence of collective interest and the establishment of collectively institutionalized spaces are important. Within these spaces, opinions are expressed and decisions are made by community members.

Most common credit lines are: a) Productive Credit, aimed at the creation or development of micro, small and medium enterprises, individual or collective ones; b) Consumption Credit, for a small loan amount, without interest rate, offered in local social currency. The aim is to stimulate consumption within the community using a local currency as well as to meet urgent and basic needs. In addition, credit lines are based on low interest rates ( $1 \%$ to $2.5 \%$ per month), to enable income increase and employment opportunities for the community. The decision-making for credit is based on a social control mechanism among community members, not in the formalism governed by laws and bureaucracy (FRANÇA FILHO; SILVA JÚNIOR; RIGO, 2012).

Social BCD currencies are an important part of a comprehensive set of actions of these community banks. So, given the complexity of the way they operate, the success of their actions depends intimately on the management strategies of the development process they stimulate, having the community as its main protagonists.

According to Rigo and França Filho (2015), the process of implementation of social currencies in the territories requires ability and creativity from BCDs, as far as facing challenges is concerned. Overall, the activities involve residents and local traders awareness raising in order to use and accept social currency as a means of payment. In short, social currency circulation proceeds as follows: users join the system, accepting to receive or pay goods and services with social currency; users can be granted loans or part of their salary, or even directly exchange the national currency for the social currency in BCD (in Brazil, the official currency is Brazilian Real). Having the social currency, residents might use them in trades among the communities that have joined the system (and 
that are registered by a $B C D$ ). Once traders receive the currency, they use them to give change or to purchase goods within the community. At the end of this process, a network is set up, involving producers, traders, service providers and consumers, who use the social currency in their everyday life complementarily to the Brazilian Real currency.

Both the creation of the BCDs (as effective promoters of community development) and social currencies (created by BCDs in order to encourage and streamline the local economy) have been considered as ST by many scholars. It turns out that, as stated earlier, there is a shortage in this research field in defining what is actually being considered "social technology", as well as on the reasons why the bank or social currency themselves should be considered as such. Thus, we propose a reflection upon the concept.

\section{Social Technology and the Role of Knowledge and Participation in Community Problem Solutions}

The term Social Technology (ST) derives from the concept of appropriate technology (AT), which was spread in the 1970s within the debates by the Intermediate Technology Development Group (ITDG), supported by the economist Ernest Friedrich Schumacher. This ideological movement (and its manifestations) emphasizes technology as people-centred, focusing on the use of sustainable technologies as a solution against poverty and as a way to promote development in developing countries. According to Dagnino (1976, p. 86), AT can be identified by "a set of production techniques which uses the features available in some society in an optimum way thus maximizing their well-being". In most cases, the technologies employed as AT were brought in from developed countries with the associated problem that development models of advanced countries could not work in countries with lower levels of economic development. Thus, a weakness in the technology transfer of AT was inbuilt. An essential human factor for the success of this type of technology - the participation of the local actors - was missing, which made it difficult to have technology transfer and its incorporation by the communities.

This weakness was tolerated because, for a long time, technology was seen as a "culturally-neutral" factor, without considering the changes required to introduce such technology in a given society. It is vital that the transfer processes to future users pay particular attention to the technological assimilation of communities and to the incorporation of such technology in their cultural and social habits (NARVÁEZ, 1996). Their implementation plays a leading role in the processes of social change, determining actors' positions and behaviors, and the social distribution structures, production costs, and access to goods and services (ILHA; RIBEIRO, 2012). As Novaes and Dias (2009) explain, AT developers were not able to design a process that could allow the generation and diffusion of alternative knowledge, through the participation of local actors.

As the AT movement did not observe accuracy to the necessity of empowering local actors and inserting their knowledge and culture since the very technology design, a wave of critical movement grew in the 1980s. As Dagnino, Brandão and Novaes (2004) explain, the concept of ST is precisely an evolution from the criticism and additions made to the AT concept, avoiding the influences and perceptions of groups of researchers from the first world. 
Since the 1980s, under the strong influence of the neoliberal system and the consequent increase in existing social and environmental problems, concern grew about technological bases, which could promote more sustainable development through the knowledge of the social actors involved with the problem. As a result of the seek for a new conceptualization and action, the concept of Social Technology (ST) ("Tecnologias Sociais", in Portuguese), was developed in Brazil during the decade of 2000 by a network of researchers, social movements and organizations, as a response to the criticisms of AT.

The most important difference that distinguishes ST from AT is that, in ST, the process of generation and diffusion of alternative knowledge occurs through the participation of local actors (DAGNINO; BRANDÃO; NOVAES, 2004). Although there is no official definition for the concept of ST, its is understood, in general terms, as products, techniques or methods that can be reapplied, developed and/or applied in interaction with a community, which represent social transformation solutions through the sustainable use of local resources (RTS, 2011). According to Dagnino, Brandão and Novaes (2004), the active participation of the actors is an essential ST element; without them, the ST would not occur.

The ST concept recognizes people's wisdom and scientific knowledge, acting as a bridge between social demands and solutions, through the application of local knowledge (ITS, 2007). The Instituto de Tecnologia Social (Social Technology Institute) considers ST as a set of techniques and methods, developed and/or applied in interaction with the population, being appropriate to it, representing solutions for social inclusion and improved living conditions. They try to respond to the existing social problems, that is, instead of using conventional technologies, they try to be a bridge between social demands and solutions through the application of local knowledge (ITS, 2007).

But, as affirms the members of Rede de Tecnologia Social (Social Technology Network) (RTS, 2010), to be consider an ST, the products, techniques or methods must be able to be reapplied. For ST, reapplication implies that it must be recreated in new places, appropriate to their reality, bringing new knowledge and meanings (MIRANDA; LOPEZ; SOARES, 2011). Reapplication is a key concept for ST implementation. It differs from a simple replication, in the sense that, in a replication process the object is merely duplicated. Whereas, in a reapplication process, all the specific new factors involved in the community (reality of the territory, actors involved, local available resources, etc.) are observed and taken into account within a new application process of the same ST (LASSANCE; PEDREIRA, 2004; ILHA; RIBEIRO, 2012).

In this sense, the reapplication process is crucial within the ST concept, since it is part of the scaling up. Scaling up small-scale successful projects is said to lead to more quality benefits for more people over a wider geographical area, more quickly, more equitably and more enduringly (FRANZEL; DENNING; LILLESO; MERCADO, 2004). Furthermore, the focus on the reapplication process is not the reapplication of specific elements of a given technology, but the process that allowed the project to succeed, the local roots and conditions that can sustain the change.

The movement towards ST development and adoption is increasing year by year in Brazil (RTS, 2010). This empowerment occurs in different areas of technology development: (i) the wide range of actors involved (non governmental organizations, most- 
ly nonprofit ones, universities, government agencies and social movements) exchange knowledge within a participatory process in the ST project cycle (ASHBY, 2003); and (ii) the wide range of techniques and resources covered under different areas, such as: assistive technologies, local development of communities, food safety and financial solutions (RTS, 2011). Likewise, different socio-economic processes and natural resources, such as energy, water availability and human health, are covered by ST (VENTURA; FERNANDES; ANDRADE, 2012).

As previously stated, the main objective of ST is to solve social or environmental problems. Therefore, ST can be considered as a tool to promote improvement in communities and regions, making use of the human aspect of a technology as one of the main tools to achieve it. More recently, a new kind of development tool, developed by communities to solve their local problem of few financial resources, has been considered as a kind of ST: social currencies.

It is important to point out that ST concept, the BCDs and their social currencies were almost born together, in the late 1990s, beginning of 2000s. In fact, they represent bottom-up attempts, strongly supported by non-profit organizations, to generate development alternatives to social problems faced by communities all around the world.

Countries created institutions to promote and scale up this kind of technology, as a support and empowerment strategy of social innovation promotion to create development in new forms. The most important institution to support and promote the community banks in Brazil is the National Secretariat for Solidarity Economy/Secretaria Nacional de Economia Solidária (Senaes). The Senaes is attached to the Ministry of Labor and Employment/Ministério do Trabalho e Emprego (MTE). For example, in 2013, the second public call from Senaes involved about 11 million Brazilian Reais (about US\$ 5 million dollars at that period, considering the rage value in that year). The public calls from Senaes address nonprofit organizations that have know-how on the creation process of community banks in Brazil. Among these organizations, we could highlight the University Incubators and their teams, which involve teachers, graduate and undergraduate students.

In this sense, the recognition of BCDs and their social currencies as ST is being done by institutions in Brazil. The Banco do Brasil Foundation, a nonprofit institution attached to Banco do Brasil, is certifying social currencies as ST in the country. Together with Senaes, Banco do Brasil Foundation and other important institutions (as Finep, ${ }^{3}$ Financiadora de Inovação e Pesquisa/Funding of Innovation and Research) are also stimulating ST creation and reapplication all around Brazil. It maintains a database with all the ST experiences that were approved by the institutions as a real ST development tool.

In Table 1 we systematize the BCDs and their social currencies that received a formal acknowledgment, stating that such experiences really incorporated the ST requisites (social participation, seek of social transformation, community solving problem and possibility of reapplication).

\footnotetext{
${ }^{3}$ Important nonprofit institution that promotes economic and social development through support of Science, Technology and Innovation in companies, universities, technological institutes and other public and private organizazions.
} 
Table 1 - BCDs and their social currencies that received a formal acknowledgment as ST

\begin{tabular}{|c|c|c|c|c|}
\hline Social Currency & Developer & Community & $\begin{array}{l}\text { Certificatory } \\
\text { Institution }\end{array}$ & $\begin{array}{l}\text { Year of } \\
\text { Recognition }\end{array}$ \\
\hline Kiriris & $\begin{array}{l}\text { Fonte de Água } \\
\text { Fresca Community } \\
\text { Development Bank }\end{array}$ & $\begin{array}{l}\text { Encanto da Cidade } \\
\text { neighborhood } \\
\text { (Municipality: } \\
\text { Ouriçangas/Bahia) } \\
\end{array}$ & $\begin{array}{l}\text { Banco do Brasil } \\
\text { Foundation }\end{array}$ & 2015 \\
\hline Maracanã* & $\begin{array}{l}\text { Pajuçara } \\
\text { Community } \\
\text { Development Bank }\end{array}$ & $\begin{array}{l}\text { Pajuçara neighborhood } \\
\text { (Municipality: } \\
\text { Maracanaú/Ceará) }\end{array}$ & $\begin{array}{l}\text { Banco do Brasil } \\
\text { Foundation }\end{array}$ & 2007 \\
\hline Muiraquitã & $\begin{array}{l}\text { Muiraquitã } \\
\text { Community } \\
\text { Development Bank }\end{array}$ & $\begin{array}{l}\text { Municipality: Santarém/ } \\
\text { Pará }\end{array}$ & $\begin{array}{l}\text { Banco do Brasil } \\
\text { Foundation }\end{array}$ & 2011 \\
\hline Palmas** & Banco Palmas & $\begin{array}{l}\text { Conjunto Palmeira } \\
\text { (Municipality: Fortaleza/ } \\
\text { Ceará) }\end{array}$ & $\begin{array}{l}\text { FINEP (Studies } \\
\text { and Projects } \\
\text { Financer) }\end{array}$ & 2008 \\
\hline Vale Solidário & $\begin{array}{l}\text { Coofeliz } \\
\text { Cooperative }\end{array}$ & $\begin{array}{l}\text { Municipality: Espera } \\
\text { Feliz/Minas Gerais }\end{array}$ & $\begin{array}{l}\text { Banco do Brasil } \\
\text { Foundation }\end{array}$ & 2013 \\
\hline Veredas & $\begin{array}{l}\text { Community } \\
\text { Chapadense } \\
\text { Development Bank }\end{array}$ & $\begin{array}{l}\text { Municipality: Chapada } \\
\text { Gaucha/Minas Gerais }\end{array}$ & $\begin{array}{l}\text { Banco do Brasil } \\
\text { Foundation }\end{array}$ & 2013 \\
\hline Verde & $\begin{array}{l}\text { Verde Vida } \\
\text { Community } \\
\text { Development Bank }\end{array}$ & $\begin{array}{l}\text { Bacia do Rio Aribiri } \\
\text { region (Municipality: Vila } \\
\text { Velha/Espírito Santo) }\end{array}$ & $\begin{array}{l}\text { Banco do Brasil } \\
\text { Foundation }\end{array}$ & 2015 \\
\hline
\end{tabular}

Source: Own elaboration (2015).

* In this case, the Bank was certified as a social technology, not the social currency.

** In this case, the Instituto Palmas, created in 2003 to disseminate the Banco Palmas technology, was certified, not the social currency.

\section{METHODS}

As mentioned before, the present study represents the attempt of creating a new investigation area, linking two different Ph.D theses. Thus, the reflections presented here are the result of years of research and deep analysis of experiences in Brazil and some other countries.

Specifically in the present paper, besides the literature review, we opt for a deep empirical research, which allows understanding the relationship between BCDs and social currencies, taking into account the concept of the ST. To do so, we chose the case study of Banco Palmas, the first Brazilian community bank, created in 1998.

The main corresponding research process carried on this paper occurred in two phases between 2012 and 2013. The first phase, in January 2012, consisted of an ethnographic research in the first and greatest community bank in Brazil, Banco Palmas. The second phase took place during one week in October 2013 in order to deepen the data and confirm previous results from the first phase.

In the first phase, the method to explore the study object was the ethnographic research. We observed the Banco Palmas in Conjunto Palmeira in Fortaleza (northeastern Brazil) on a daily basis, trying to explore the community bank creation process, from the point of view of its methods, techniques, participation process and other ele- 
ments. The immersion lasted 26 days and allowed us to understand the history of the neighborhood, the creation of the Community Bank and its modus operandi. The main focus was to try to observe the real presence of a ST development and implementation process. During this period of immersion, it was possible to carry out thirteen semi-structured interviews with key actors in the Banco Palmas and the community. The semi-structured interviews were applied with the general coordinator of Banco Palmas, the coordinator and two collaborators of the social projects team, one financial manager, two loan officers and two administrative manager. In addition to these interviews, conversations with local leaders took place on a daily basis, with five members of the community with a significant role in the neighborhood and in the process of setting up Banco Palmas and other local social organizations. Others interviews had an open character and they did not rely on standardized instruments. The presence of the researcher at Banco Palmas made it possible to follow some internal processes of the organization, such as the granting of credit, the work of the bank tellers and the development of some social projects. This phase of the research provided detailed field notes, comprising information from the subjects as well as impressions of the researcher (VIEIRA; PEREIRA, 2005). In addition, observations and informal conversations were important sources of information to support the development of semi-structured scripts for intentional interview samples throughout the research process (QUIVY; CAMPENHOUDT, 1998).

At the end of the first phase, a concern emerged. Since Banco Palmas was recognized as ST by Finep, it was necessary to verify the effectiveness of an important ST requisite: the reapplication process. So, we felt the need to broaden the scope of the research, trying to understand the reality of other Brazilian community banks, their specific features and operational pattern, and, mainly, the influence of the Palmas experience for their creation. Then, a survey was undertaken in the network of community banks, which was (and is) being formed in the country. This second step allowed us to map and understand the BCDs in Brazil, and the importance of Palmas in this process. Therefore, we followed an inductive movement from particular to general. From the particularities found in the Banco Palmas, we developed a questionnaire and applied it in 47 out of 78 community banks in the country, located in various states ${ }^{4}$.

Besides that, seeking to analyze the Banco Palmas and Palmares social currency as real STs a deep research was carried out to better understand elements mentioned by the interviewed actors, as the PLIS Process, developed by Instituto Palmas (which will be described in the next section), and the role of the Brazilian government in the reapplication process. In this phase, qualitative analyses were done taking in account the main principles of the ST concept: technology focused on a social problem solution, community participation on its creation and reapplication possibility. Despite the application in the field ensured greater consistency in the data and the capture of new information, in this paper, we just consider some qualitative data about their social currencies, which had real links to ST reapplication.

\footnotetext{
${ }^{4}$ The data from the survey are not related with the object and proposal of this paper. The survey data were only used to offer an overview about community banks and social currencies in Brazil. More information about the survey, see Rigo and França Filho $(2015,2017)$.
} 


\section{DISCUSSION}

\section{Bank Palmas: \\ Creation and Operation of a New Type of Social Technology}

Banco Palmas was created in 1998, by the Conjunto Palmeira Association (Associação dos Moradores do Conjunto Palmeira/Asmoconp). The Asmoconp ${ }^{5}$ was created in 1981, almost ten years after the arrival of the first residents in the neighborhood, considered one of the poorest and most vulnerable in the city of Fortaleza, Ceará state. In fact, its constitution was the result of political struggles and social movements of the residents in the neighborhood. Through lobbying, public demonstrations and discussions organized by them, the community organized itself to guarantee its numerous claims (like water and public transportation) were attended to.

Even in the 1990s, 26 other associations were organized in the neighborhood with different objectives: collective production, children and adolescents' care, teaching and dance performance, circus arts, among others. These organizations layed the key role to discuss the guidelines for diagnosing and solving common problems. Several actions were taken, such as a community newspaper called "Acorda Palmeira" (Wake up Palmeira) (BORGES, 2011).

In addition to these organizations, currently the community has nine schools and two health centers. The set of the Conjunto Palmeira associations meets at the Socioeconomic Local Forum/Fórum Socioeconômico Local do Conjunto Palmeiras (Fecol). Organized by the first Association and the Banco Palmas, Fecol is a monthly meeting with the participation of representatives of the various neighborhood organizations to discuss matters related to the community.

Throughout the existence of the association, setting up seminars for discussion and resolution of common problems was a constant issue. However, whereas many problems were solved, such as water and energy (and, partially, sanitation and transportation), others remained yet: employment and income generation. In a sense, advances in social and political issues of the neighborhood served as the basis for residents to begin to discuss and advance proposals on economic issues. The search for employment and income has become even more essential for many people in the neighborhood, to effectively improve their quality of life. It was this concern that arose the idea of the creation of the Banco Palmas, almost twenty years after the creation of the association. The goal was to create an organization that could provide credit to the poorest, alleviating poverty and facilitating the creation of new productive activities. That is, it was developed, in a collective and participatory way, a method able to provide conditions for the creation of employment and income-generating activities. Thus, a new type of ST was born, non-existent in Brazil: the Community Development Bank.

Therefore, it is observed that, since the beginning of its history, Conjunto Palmeira had a feature that would become essential for the subsequent creation of the Banco Palmas. Its residents have always been directly involved in finding solutions to their so-

${ }^{5}$ In 2012, the association had 1,500 members. Its general meetings are open to all residents, whether associated or not, when the matter concerns the situation of the neighborhood. 
cial problems. They were directly involved in the conquest of the necessary advances (in the case of basic rights acquired), but also through their numerous local organizations, they began to develop procedures to improve life quality. This local search for solutions to their problems is the basis for the creation of ST, as affirmed by Ventura, Fernandez and Andrade (2012).

The onset of activity of loans that would be made by the Banco Palmas was made possible by a donation of 2,000 Brazilian reais, granted by the local Catholic Church. It is important to highlight here a key requirement of ST: the effective involvement of various social actors to solve the existing problem together.

However, the local community involved with the management of the bank noticed that, besides the existence of financial resources that could be used to serve as an initial contribution to the creation of productive activities, it was necessary to ensure that these generated funds would remain in the neighborhood. Only that way, it would be possible to effectively drive the local economy. Moreover, it was necessary to ensure that the residents who did not have proper financial resources, but who owned other assets with exchange value, would be given the opportunity to enter the local financial circuit.

Hence, in 2001, the Palmares currency was created, and it was used by Banco Palmas within an exchange club, conducted by community residents, interested in exchanging goods and services. Local managers highlight the wealth of the Palmares currency creation process, for which several meetings were held to collectively decide its layout and name. For the Banco Palmas coordinator, Joaquim de Melo Neto, "the process is very rich because it creates a currency, a value. Money dominates us, so the fact that a community creates its own currency is an empowerment process (BANCO PALMAS COORDINATOR, 2012)".

In fact, as specified by ST researchers, as Dagnino, Brandão and Novaes (2004) and Novaes and Dias (2009), community empowerment for the use of technology, and their effective participation in the creation or implementation processes, are key to the real adoption of this very technology in a given reality, and for its proper functioning. As technologies are people-centred, the participation of the local actors is essential for its success. In Banco Palmas its was possible to see that this participation occurred since the definition of how to solve their income generation problem.

The Palmares currency, used only within the exchange club, was created and printed by the Banco Palmas itself and without take care against counterfeit. At the end of each meeting, the producers and consumers gave back the Palmares they had received for their goods and services. With the exchange club, they began to experience a "mismatch" between supply and demand for food products, the item participating residents sought the most. Most wore for clothing and craft trade, while the high demand was for food. Moreover, in the exchange club, it was difficult to set the price of the items people brought. The idea of the exchange club was only to facilitate the exchange of the surplus of what people produced or were able to do. However, this exchange system no longer met the needs of the participants causing its emptying. 
The questions surrounding the exchange club led to the creation of a new currency with a new proposal. It was necessary to change the layout of the currency and manufacture it with safety mechanisms to facilitate its acceptance by neighborhood merchants. So, since the Banco Palmas was already known in the territory (since 1998) and had projects that kept the "Palmas" brand in the name (such as Palmatech and Palmacard), they decided to change the name for "Palmas" in 2002. The replacement process was immediate. Once more, it was possible to notice the necessity of the community and its knowledge and culture influencing the technology design. Following the orientations of ST researchers, as Dagnino, Brandão and Novaes (2004), the process of generation and diffusion of the technology involved the use and respect of alternative knowledge, through the participation of local actors.

For the manufacture of the social currency, the Banco Palmas sought partnership in Argentina, for in Brazil they were not able to do such work, graphically speaking. There are four security mechanisms in the Palmas social currency and in other social currencies linked to BCDs in Brazil: a) the serial number, by which they are registered; $b$ ) the watermark, which hinders printing; c) the bar code; and d) an ultraviolet mark for reading. All these mechanisms were essential not only to avoid counterfeit, but also for merchants to accept the currency. As highlighted by ITS (2007), the ST concept recognizes people's wisdom and scientific knowledge, acting as a bridge between social demands and solutions. These kind of partnership was totally aligned with this necessity.

In the first release of Palmas in the Conjunto Palmeira, only two merchants in the community accepted the social currency. As more enterprises realized that the business of those two competitors was increasing, they also started accepting it. According to the registration list of the Banco Palmas, nowadays there are 240 businesses that accept Palmas in the neighborhood and surrounding region. However, it is estimated that a larger number do so, given the fact that many receive it on an informal basis, not registering it and using it to buy inputs within the neighborhood itself.

Another mechanism that provides security to merchants and users in general is the ballast system. For each Palmas currency circulating in the community, there is a correspondent in Brazilian Real in a traditional bank account. This is particularly important for traders from the neighborhood, because their suppliers are not in the neighborhood, which forces them to do much of their shopping abroad. Moreover, this is also a requirement of the Central Bank of Brazil. In addition to the ballast and reliability in the currency, it was important to use various outreach mechanisms of traders and neighborhood residents about the importance of using social currency for the community. As reported by Sandra Magalhães, "it is important that many merchants accept the currency so that consumers know what to do with them [where to spend]". (BANCO PALMAS SOCIAL PROJECTS COORDINATOR, 2012).

Hence, the Banco Palmas used a set of mechanisms that encouraged the acceptance and circulation of the currency. With such mechanisms, they sought ways to explain issues to the community, such as economy and solidarity finance, local consumption and social currency, among others related to them. Therefore, videos, small books, songs, plays, and even a printed soap opera were developed in order to explain to community members about the bank and currency. The idea was to sensitize traders to accept the currency and people to buy in the neighborhood. The slogan was "Compre no 
bairro, é mais trabalho (buy in your neighborhood, it means more jobs)." In this mechanism, the community and its residents' history were emphasized. Once again, there is empowerment and the sense of belonging, one of the relevant factors to the acceptance and use of ST.

For example, in the soap opera, they present characters of the neighborhood, showing the name of the trades in which the social currency was accepted, what types of products could be bought, and other details. Another interesting example was the exercise books used in schools. The exercises were answered by students after workshops held by the Banco Palmas team together with teachers. Currently, although these materials are no longer being made with such regularity, the discussions in spaces that were created, such as the Art and Culture Forum (in which all the neighborhood cultural groups meet every three to four months) and Fecol, also serve to reflect upon these topics.

Both for emissions of currencies in the community and its control, there is a set of tools. Spreadsheets are created to facilitate the work of community banks. Even because "people who work with it do not often have much schooling" (BANCO PALMAS ADMINISTRATIVE MANAGER, 2012).

On the emission worksheet of the social currency, the serial number ${ }^{6}$ is registered. For example, the numbers from 1 to 200 are designed for 20050 -cent bills. It means that 100 Palmas are available to circulate within the community. In addition, knowing which serial numbers were released, they are able to identify counterfeiting. As they launch new money, new sheets are filled considering the information from previous sheet. Thus, the last sheet shows a total amount and the volume of currency in circulation, and all the previous spreadsheets provide the history of releases of social currencies in the community. Table 2 is the spreadsheet model that the Banco Palmas uses and offers to other community banks when setting up a new social currency by BCD.

Table 2 - Spreadsheet model for issuing Banco Palmas social currency

\begin{tabular}{|c|c|c|c|c|c|}
\hline \multicolumn{4}{|c|}{ CURRENCY EMISSION CONTROL } & \multicolumn{2}{|c|}{ RECORD № 0001/2011 } \\
\hline \multirow{4}{*}{ DATE } & \multirow{4}{*}{ HISTORY } & \multicolumn{4}{|c|}{ CURRENT- BANKNOTES CASH } \\
\hline & & \multicolumn{4}{|l|}{ RESUM } \\
\hline & & \multicolumn{2}{|l|}{ EMISSION } & \multicolumn{2}{|l|}{ BALANCE } \\
\hline & & \begin{tabular}{|l|} 
No \\
BANKNOTES
\end{tabular} & VALUE & \begin{tabular}{|l|} 
No \\
BANKNOTES
\end{tabular} & VALUE \\
\hline \multirow{5}{*}{ 08/07/2011 } & BANKNOTES 0,50 - 0001 A 0200 & 200 & $R \$ 100,00$ & 200 & $\mathrm{R} \$ 100,00$ \\
\hline & BANKNOTES 1 - 0001 A 0200 & 200 & $R \$ 200,00$ & 200 & $R \$ 200,00$ \\
\hline & BANKNOTES 2 - 0001 A 0100 & 100 & $R \$ 200,00$ & 100 & $R \$ 200,00$ \\
\hline & BANKNOTES 5 - 0001 A 0050 & 50 & $R \$ 250,00$ & 50 & $R \$ 250,00$ \\
\hline & BANKNOTES 10 - 0001 A 0025 & 25 & $R \$ 250,00$ & 25 & $R \$ 250,00$ \\
\hline \multicolumn{2}{|l|}{ TOTAL } & 575 & $\mathrm{R} \$ 1.000,00$ & 575 & $\mathrm{R} \$ \mathbf{1}^{1.000,00}$ \\
\hline
\end{tabular}

Source: INSTITUTO PALMAS (2012).

\footnotetext{
${ }^{6}$ For each interval, banknotes are printed for each value (usually 0.50, 1.0, 2.0, 5.0 and 10.0). Furthermore, the banknotes are dropped from the samples to emission sheets. Generally, community banks set aside a small portion of each value to serve samples.
} 
After the emission, the social currency circulation is also controlled based on a worksheet. Each type of transaction made with social currency in BCD is registered, be it as direct exchange (for social currency), loans, payments etc.

As previously mentioned, the Palmas, as well as Brazilian social currency of community banks, depends on the existence of the ballast. In the case of Banco Palmas, a smaller part of the ballast is stored in safes in the bank itself and the majority in a standard bank account. The ballast of social currency is not applied in the form of investments or used for other purposes. The aim is to ensure that, at any time, all the social currency in circulation can be exchanged for official currency (Brazilian Real).

According to the office manager interviewed at Banco Palmas, the instruments and the way they control the currency is taught to new community banks, but each of them can make the changes they consider necessary. This careful with future BCDs that could be interested in the use of the technology demonstrates, once more, we are in front of an ST. The technology wasn't only created to solve a social problem with the community participation. It was designed to make possible its reapplication in other contexts, with the respect of each particularity, what will be better explained in next section. As said before, the focus on the reapplication process can not be the reapplication of specific elements of a given technology, as Palmares currency, but the process that allowed its use in different contexts. The current challenge is to build a common software for all BCDs to support control of their social currency, as well as the bank management.

In addition to the social currency management and the Banco Palmas management themselves - a number of other activities of different projects are carried out. For instance, there is a team specifically designed for the management and implementation of social projects for the community and surrounding region (training, creation of specific solidarity enterprises, targeted projects for women, and many others).

Social projects of the Banco Palmas are fundamental and they follow their demand for territorial development through the granting of credit. They are facing a number of issues, such as those related to culture and education. Each of these projects is supported by different public or private institutions and partners, through the participation of the Palmas Institute or the Asmoconp Association. Yet, there is training in many different areas, focusing on community demands. "That way, Banco Palmas is always training people from its community for work and for life" (BANCO PALMAS SOCIAL PROJECTS COORDINATOR, 2012). Once again, there is the full relationship of the Banco Palmas philosophy employed in ST. Generally, by seeking to solve a particular social problem, the actors involved in trying this solution eventually develop technology strategies that go beyond the problem itself. Thus, in most cases, a particular ST is able to assist in solving different problems afflicting a given population.

In the early 2000s, the activities of the Banco Palmas became more complex as other demands of the residents emerged and were identified. The management team then began to seek information on other experiences, to strengthen actions and improve the functioning of the Banco Palmas. This search for new knowledge ended up providing the empowerment of local communities to manage their technology. The community ownership for the use of a particular method or product is considered a necessary condition for recognition as an ST. 
To get an idea of the volumes that have circulated in Palmas, in January 2012, it was estimated that almost 40,000 Palmas circulated in the neighborhood. According to Banco Palmas, in 2009 this volume of currency was enough. It was gradually released into the community through a number of mechanisms. One of these mechanisms is loans for consumption in Palmas (up to 600 Palmas). Another way to launch social currencies in the community is paying part of bank members' salary in Palmas (10\% of the salary). Some local partner organizations can do the same. To encourage the exchange of Brazilian Real for Palmas, some merchants offer about 5\% discount on purchases with the social currency.

Questioned in a survey in 2008 about the reasons why using Palmas social currency, most residents said they meant to help trade in the neighborhood. The results of this research demonstrated the positive effects of the awareness-raising process on the use of social currency undertaken by Banco Palmas. At that time, both traders and residents grasped the role of social currency and its positive potential effects on the territory (SILVA JÚNIOR, 2008). This first evaluation comprised 253 respondents, of which $58 \%$ said they use or had used the Palmas social currency in 2008.

\section{Understanding the Banco Palmas as a Social Technology in the Reapplication Process}

After four years of its establishment, the management team started to feel the need to create a new legal form. Therefore, in 2002, the Palmas Institute arises, set up in the legal form of microcredit Oscip ${ }^{7}$ (Organização da Sociedade Civil de Interesse Público/Civil Society Organization of Public Interest). This creation was needed before the requirement of partnerships and projects (considering that the Banco Palmas has no legal entity and the legal form of associations is not suitable for certain purposes, projects and partnerships).

Later, the Institute would also be important to expand the experience of the Banco Palmas to other neighborhoods in Fortaleza city, Ceará state, to several municipalities, other states and even other countries. Nowadays, despite the increased visibility of the Banco Palmas and the "Palmas trade mark", the Institute is largely responsible for facilitating reapplication of ST in Brazil.

Currently, the Institute maintains a website containing several videos, publications and information that help other communities wishing to implement ST community banks and social currencies. In addition, the Institute has been working directly in community mobilization and in promoting capacity building. This is done, with the support, for example, from Senaes and Banco do Brasil Foundation, which contribute with funds to the reapplication of ST in Brazil. Examples of this work favoring ST reapplication may be found in Chapadense, Maracanã and Fonte de Água Fresca community banks, already certified as ST, citing the support of the Institute as critical to their development and deployment process.

The Oscip are non-governmental organizations that obtain a certificate issued by the federal government to prove compliance with certain requirements, especially those derived from administrative transparency standards. In contrast, they may take part in contracts with the government (federal, state and municipal). 
One of the main tools developed by the Palmas Institute, which has been of great importance for the reapplication of ST, is the publication of Plies (Strategic Local Investment Plan - A Method for Generating Work in Low-Income Territories). In this material, the Institute presents step-by-step the methodology established by the Banco Palmas so that, in a participatory manner, a community can develop its investment plan for the neighborhood, writing the strategic projects for income generation in the community. After presenting the general methodology, the history and the social organization process of the Conjunto Palmeira and Banco Palmas are presented in the Plies.

Since the origin of BCDs in Brazil, from the creation of the Banco Palmas in 1998 in Fortaleza (Ceará), this BCD Network is being created. Notably, since 2002, with the creation of the Palmas Development Institute and Solidarity Socioeconomics, the establishment of partnerships with other public and private institutions has enabled its expansion, strengthening the involvement of other supporting organizations in the methodology creation of BCDs. In 2004, the second BCD in Brazil was created, also in Ceará state; in 2009, there were 49 BCDs; and, in May 2012, the Brazilian BCD-Network comprised 78 BCDs. By the end of 2013, there were 103 BCDs located in several states. In this group, 52 BCDs are located in the Northeast Region; 16 in the North; 6 in the Midwest; 25 in the Southeast and 1 BCD in the Federal District. The state with the highest number of BCDs is Ceará (37), followed by São Paulo (10) and Bahia (8).

The ways of creating and supporting BCDs vary according to the expertise of each support organization and the specificities of the region or territory. Thus, different institutional arrangements can be made, but some aspects are common and are shared in methodological terms by the organizations involved. The main one concerns the identification of a concrete demand of the territory, which collectively manifest and indicate certain endogenous mobilization on the proposal. This is essential, given that it is the most organized community that manages the activities of the BCD and the resources involved.

\section{CONCLUDING REMARKS AND RESEARCH AGENDA}

In Brazil, both social currencies and community banks have strong focus on social transformation in its creation and use processes. Facing this goal of transformation, we approached the social currency use and community bank methodology to another concept, also related to the search for improved quality of life and effective social change: social technologies. Although still considered by many a concept under construction, ST has been widely used in Brazil. At the same time, the community banks and their social currencies are considered ST by many Brazilian scholars, although they don't present a characterization of why it is really a ST or not. Thus, we proposed, in this paper, to reflect upon these experiences, bringing them closer to the concept of ST. As a result, we argued that the reapplication process possibility is the main aspect that links social currencies and community banks to ST. Besides that, the paper allowed to know in detail how the implementation of this social technology and its reapplication was given, seeking to fill a gap existing in literature, as previously mentioned. 
In addition, we noticed that social currencies have been acknowledged as ST, that is, as techniques, methods or procedures developed in interaction with the beneficiaries of the technology, subject to reinvestment, and capable of generating social change. Action result of nonprofit and governmental organization has highlighted the potential of these experiences as a technology, capable of bringing social transformation.

In the present study, we presented and analyzed one of the most famous social currencies in the world: the Palmas, created by the Banco Palmas and its Institute. The Banco Palmas methodology and the social currency use have been reapplied all over Brazil, with the support and acknowledgement from important institutions in the country, such as the Senaes and Banco do Brasil Foundation, both from the federal government.

As seen in the results, it is possible to affirm that both Banco Palmas and its social currency, the Palmas, can be considered an important ST that is being reapplied to solve economic problems in underdeveloped regions. The creation of Instituto Palmas is important to disseminate alternative forms from non-public organizations, of changing people's lives and their communities. During the social currency use, people also participate in educational processes at other levels, such as groups, cooperation, collective enterprises and many others.

As a future research, we suggest some analysis on how BCDs that received the support to reapply this ST use the information, methods and previous results, trying to understand the reach of the technology. Also, it should be important to compare the results, seeking to understand if it is possible to affirm that this ST is, in fact, a tool of development that can be spread to other poor and vulnerable communities.

\section{REFERENCES}

ASHBY, J. Introduction: Uniting Science and Participation in the Process of Innovation - Research for Development. In: POUND, B.; SNAPP, S.; MCDOUGALL, C.; BRAUN, A. (ed.). Managing Natural Resources for Sustainable Livehoods: uniting science and participation. London: Earthscan Publications Ltd. and the Internacional Development Research Center, 2003.

BANCO PALMAS ADMINISTRATIVE MANAGER. Bancos Comunitários e Moedas Sociais: o caso Palmas. [jan. 2012]. Interviewer: Ariadne Rigo. Fortaleza.

BANCO PALMAS COORDINATOR. Bancos Comunitários e Moedas Sociais: o caso Palmas. [jan. 2012]. Interviewer: Ariadne Rigo. Fortaleza.

BANCO PALMAS SOCIAL PROJECTS COORDINATOR. Bancos Comunitários e Moedas Sociais: o caso Palmas. [jan. 2012]. Interviewer: Ariadne Rigo. Fortaleza.

BAVA, S. C. Tecnologia social e desenvolvimento local. In: FUNDAÇÃO BANCO DO BRASIL. Tecnologia social: uma estratégia para o desenvolvimento. Rio de Janeiro: Fundação Banco do Brasil, 2004. p. 103-116 BLANC, J. Penser a pluralité des monnaies à partir de Polanyi: un essai de typologie. In: HILLENKAMP, I.; LAVILLE, J. L. (ed.). Socioéconomie et démocratie: I'actualité de Karl Polanyi. Toulouse: Éres, 2013. p. 241269.

BLANC, J. Classifying "CCS": community, complementary and local currencies types and generations. International Journal of Community Currency Research, 15 (Special Edition), 2011.

BLANC, J. Las monnaies paralléles: èvaluation du phénomène et enjeux théoriques. Revue d'économie financière, 49, p. 81-102, 1998.

BORGES, A. Banco Palmas como uma plataforma de desenvolvimento comunitário. In: MORAIS, L.; BORGES, A (Org.). Novos paradigmas de produção e consumo. São Paulo: Instituto Polis. 2011. p. 249-294.

DAGNINO, R. P. Tecnologia apropriada: uma alternativa? Master Project. Brasília: Departamento de Economia; Universidade de Brasília, 1976. 
DAGNINO, R. P.; BRANDÃO, F. C.; NOVAES, H. T. N. Sobre o marco analítico-conceitual da tecnologia social. In: LASSANCE, A.; PEDREIRA, J. (org.). Tecnologia social: uma estratégia para o desenvolvimento. Rio de Janeiro: Fundação Banco do Brasil, 2004.

FAIRE MOUVEMENT. Synthèsis des débats: Repport of the Rencontre Internationale des Acteurs des Monnaies Sociales et Complémentaires I. 2011. Available from: monnaieendebat.org. Cited: 2013.

FRANÇA FILHO, G. C. de; SILVA JÚNIOR, J. T. Bancos Comunitários de Desenvolvimento (BCD). In: CATANNI, A. D. et al. (ed.). Dicionário Internacional da Outra Economia. Portugal: Edições Almedina. 2009. p. 31-37. FRANÇA FILHO, G. C. de; SILVA JÚNIOR, J. T.; RIGO, A. S. Solidarity finance through community development banks as a strategy for reshaping global economies: lessons from banco palmas. Revista de Administração Pública, 47(3), p. 500-515, 2012.

FRANZEL, S.; DENNING, G. L.; LILLESO, J. P. B.; MERCADO, A. R. Scaling up the impact of agroforestry: lessons from three sites in Africa and Asia. Agroforestry Systems, 61, p. 329-344, 2004.

ILHA, M. S. O.; RIBEIRO, M. F. Adoption of technology by the low-income population segment: The lowcost hot water heater case. Habitat International, 36, p. 185-191, 2012.

INSTITUTO PALMAS. Annual Repport 2012, Fortaleza (intern document), 2012.

ITS. Instituto de Tecnologia Social. Tecnologia social e desenvolvimento participativo. Caderno Conhecimento e Cidadania 2, São Paulo: Ministério de Ciência e Tecnologia (MCT); Instituto de Tecnologia Social, 2007.

LASSANCE, A.; PEDREIRA, S. Tecnologia social: uma estratégia para o desenvolvimento. Rio de Janeiro: Fundação Banco do Brasil, 2004.

LEMOS, M. E.; FALCOSKI, L. A. N.; CASTRI C. M. P. Implantação de bancos comunitários e o desenvolvimento social dos territórios. Proceedings of the 70 Congreso de Medio Ambiente AUMG. 22 to 24 May 2012. UNLP, La Plata, Argentina. Available from: http://sedici.unlp.edu.ar/bitstream/handle/10915/26713/Documento_completo.pdf?sequence=1. Cited: $14 \mathrm{dez} .2015$.

MARTIGNONI, J. A new approach to a typology of complementary currencies. International Journal Community Currency Research, 16, p. 1-17, 2012.

MELO NETO SEGUNDO, J. J. Community Banks - Microcredit: The Brazil Experience. In: FONTELLES, J. B. Dilemmas in Globalization: exploring global trends and progressive solutions. PSE - Socialist Group in the European Parlament and Global Progressive Forum. 2009. p. 142-150.

MENEZES, M. S. Moedas locais: uma investigação exploratória sobre seus potenciais como alternativa à exclusão financeira a partir do caso do Banco Bem em Vitória/ES. Belo Horizonte: Cedeplar; Universidade Federal de Minas Gerais, 2007.

MIRANDA, I.; LOPEZ, M.; SOARES, M. C. C. Social technology network: paths for sustainability. Innovation and Development, vol. 1, Issue 1, 2011.

NARVÁEZ, J. Tecnologías apropiadas para el desarrollo sostenible. Perú: Itacab, 1996.

NOVAES, H. T.; DIAS, R. Contribuições ao marco analítico-conceitual da tecnologia social. In: DAGNINO, R. P. (ed.). Tecnologia social: ferramenta para construir outra sociedade. Campinas: IG; Unicamp, 2009.

QUIVY, R.; CAMPENHOUDT, L. V. Manual de investigação em ciências sociais. 2. ed. Paris: Gradiva Publicações, 1998.

RIGO, A. S. Moedas sociais e bancos comunitários no Brasil: aplicações e implicações, teóricas e práticas. 2014. Tese (Doutorado em Administração) - Escola de Administração. Universidade Federal da Bahia, Salvador, 2014.

RIGO, A. S.; FRANÇA FILHO, G. C. de. Policy Microfinance and Community Development Banks in Emerging Countries: Reaching Poor People. Academy of Management Proceedings, v. 2015, n. 1.

RIGO, A. S.; FRANÇA FILHO, G. C. de.. Bancos comunitários e moedas sociais no Brasil: reflexões a partir da noção de economia substantiva. Salvador: Edufba, 2017. Disponível em: http://repositorio.ufba.br/ri/ handle/ri/24260.

RTS. Rede de Tecnologia Social (org.). Tecnologia social e desenvolvimento sustentável: contribuições da RTS para a formulação de uma política de Estado de Ciência, Tecnologia e Inovação. Brasília, DF: Secretaria Executiva da Rede de Tecnologia Social, 2010.

RTS. Conceito de tecnologia social [on-line]. 2011. Disponível em:: http://www.rts.org.br/. Acesso em: 20 jul. 2011.

SILVA JÚNIOR, J. T. Avaliação de impacto e de imagem: Banco Palmas - 10 anos. Fortaleza: Instituto Palmas, 2008.

SILVA JÚNIOR, J. T. Gestão, fato associativo e economia solidária: a experiência da ASMOCONP/Banco Palmas. 2004. Dissertação (Mestrado) - Núcleo de Pós Graduação em Administração da Universidade Federal da Bahia (NPGA/UFBA), Salvador, 2004. 
SOARES, C. L. B. Moeda social. In: CATTANI, A. D. et al. (ed.). Dicionário Internacional da Outra Economia. Portugal: Edições Almedina, 2009. p. 255-259.

VENTURA, A. C.; FERNANDEZ, L.; ANDRADE, J. C. S. Tecnologias sociais: as organizações não governamentais no enfrentamento das mudanças climáticas e na promoção do desenvolvimento humano. Cadernos Ebape, v. X, p. 605-625, 2012.

VIEIRA, Marcelo. Milano; PEREIRA, Bill Nunes. Estudos etnográficos em administração. In: VIEIRA, M. M. F.; ZOUAIN, D. M. (org.). Pesquisa qualitativa em administração: teoria e prática. Rio de Janeiro: Editora FGV, 2005. p. 223-237. 